\title{
STRATEGI RUMAH SAKIT UMUM SWASTA DI PURWOKERTO DALAM MENGHADAPI AKREDITASI
}

\section{STRATEGY OF PRIVATE GENERAL HOSPITAL IN PURWOKERTO IN FACING ACCREDITATION}

\author{
Bernadetta Eka Noviati*1 \\ ${ }^{* 1}$ STIKes Panti Rapih Yogyakarta, Jln Tantular No. 401, Condong Catur, Kecamatan Depok, Sleman, \\ DIY 55283, email: eka.vie@gmail.com, Indonesia
}

\begin{abstract}
Background: Accreditation is an obligation that must be done by every hospital in Indonesia. Purwokerto is the capital of Banyumas district, Central Java, Indonesia. Health services in Purwokerto are facilitated by 10 Public Hospitals and 7 are private public hospitals. Based on the preliminary study, of the seven general hospitals, get one hospital that has been accredited. How is the strategy of public private hospitals facing accreditation, becoming an interesting topic to learn.

Objective: The purpose of this research is private hospital strategy in Purwokerto to face hospital accreditation.

Methods: The research method used is qualitative with phenomenology approach. Analysis the data research by using IPA (Interpretative Phenomenological Analysis).

Results: Based on the analysis of 5 informants, the theme of accreditation strategy for private hospitals that are human resources control, owner and management commitment, programmatic procedures, time management, process strategy, and building a comfortable working environment.

Conclutions: To be able of accreditation of public private hospitals need the ability to build human resources, and other resources both physical, facilities, environment and time management. Further research is expected to be implemented in all hospitals whether public hospitals, specialty, or clinics.
\end{abstract}

Keywords: Accreditation, hospital, strategy

\section{PENDAHULUAN}

Rumah sakit merupakan institusi pemberi layanan jasa kesehatan yang memiliki peran penting bagi kehidupan masyarakat. Dewasa ini rumah sakit di seluruh dunia menghadapi suatu fase strategis pembaharuan untuk berubah menjadi suatu organisasi yang fleksibel yang dapat menawarkan layanan dengan kualitas tinggi dan dengan biaya yang rendah atau terjangkau. Rumah sakit rumah sakit ini menghadapi suatu tantangan manajerial yang penting untuk mengubah strategi peningkatan pelayanan jangka panjang dengan tetap mempertahankan mutu dan kualitas pada pelayanan saat ini. ${ }^{1}$
Mutu pelayanan kesehatan dapat ditunjukkan dengan memberikan pelayanan yang memuaskan bagi setiap pemakai jasa dan sesuai dengan standar pelayanan Upaya peningkatan mutu sebaiknya dilaksanakan secara terpimpin, terarah, terpadu, menyeluruh, dan berkelanjutan. ${ }^{2}$

Akreditasi adalah pengakuan terhadap rumah sakit yang diberikan oleh lembaga independen penyelenggara akreditasi baik akreditasi nasional maupun akreditasi internasional yang ditetapkan oleh Menteri. ${ }^{3}$ Setiap Rumah Sakit di Indonesia berkewajiban untuk mengikuti proses 
akreditasi sesuai dengan peraturan yang telah ditetapkan oleh pemerintah. ${ }^{3}$

Berdasarkan studi pendahuluan diketahui bahwa jumlah rumah sakit umum swasta di Purwokerto yaitu terdiri dari 7 rumah sakit, mencapai $50 \%$ dari total rumah sakit yang memberikan pelayanan kesehatan di kota tersebut. ${ }^{4}$ Diantara rumah sakit umum swasta yang ada di Purwokerto, diketahui bahwa baru terdapat satu rumah sakit yang telah terakreditasi dengan menggunakan standar Akreditasi Rumah Sakit Versi 2012. ${ }^{5}$ Hal ini merupakan sebuah fenomena yang menarik untuk dipelajari. Sehingga penelitian ini bertujuan untuk menggali strategi rumah sakit umum swasta di Purwokerto untuk menghadapi akreditasi rumah sakit.

\section{BAHAN DAN CARA PENELITIAN}

Jenis penelitian ini adalah penelitian kualitatif dengan pendekatan fenomenologi. Fenomenologi berfokus pada makna subyektif dari realitas obyektif didalam kesadaran orang yang menjalani aktifitas kehidupan sehari-hari. ${ }^{6}$ Pendekatan ini dipilih karena permasalahan yang dikaji menyangkut fakta yang sedang berkembang di rumah sakit dimana di setiap rumah sakit di Indonesia wajib mengikuti akreditasi nasional atau bahkan internasional. ${ }^{3}$

Informan dalam penelitian ini yaitu pimpinan rumah sakit yaitu Direktur Rumah Sakit Swasta yang ada di Purwokerto. Direktur rumah sakit merupakan sosok yang sangat penting dalam organisasi rumah sakit.
Selain direktur rumah sakit swasta, salah seorang informan adalah surveyor dan pembimbing akreditasi tingkat nasional untuk rumah sakit.

Metode pengumpulan data dalam penelitian ini adalah dengan melakukan wawancara mendalam (in-depth interview) kepada para informan, melakukan observasi, dan studi dokumentasi. Selanjutnya data dianalisis dengan metoda Interpretative Phenomenological Analysis (IPA) dengan bentuk tahapan: reading and re-reading, initial noting, developing emergent themes, searching for connection a cross emergent themes, moving the next cases, dan looking for patterns across case. ${ }^{7}$

\section{HASIL DAN PEMBAHASAN}

Penelitian dilaksanakan di empat rumah sakit swasta yang ada di Purwokerto. Penelitian strategi rumah sakit swasta menghadapi akreditasi menemukan enam tema. Tema-tema tersebut dijelaskan sebagai berikut:

Tema 1: Kontrol sumber daya manusia

Pemahaman kontrol sumber daya manusia dibentuk dari empat sub tema. Sub tema pertama yang ditemukan adalah leading. Hal ini diartikan bahwa strategi menghadapi akreditasi dikembangkan dengan diawali bahwa setiap direktur rumah sakit wajib memberikan contoh dan memimpin staf di rumah sakit yang dipimpinnya. Hal tersebut seperti diungkapkan informan sebagai berikut: 
" ... direktur harus selalu terlibat... direkturnya harus selalu ada... jadi kalau ada yang butuh tanda tangan... gampang... direktur ada... bertemu gampang... ditanya gampang... “ (Informan/I3)

“ ...mereka masih sangat muda... semangatnya tinggi, 'nothing to lose', tetapi kan perlu diarahkan... mungkin berbeda dengan yang sumber dayanya tua... mungkin pengalamannya sudah banyak... na itu... yang kita harapkan... mereka mau mengajari... membagikan pengalamannya..." (I2)

“ Kesiapan mereka untuk lembur... kesiapan untuk mereka berkumpul ... keinginan memperkenalkan sesuatu kepada mereka sangat kuat..." (I2)

Dalam mempersiapkan akreditasi rumah sakit, direktur berperan sebagai leader. Pemimpin yang dalam hal ini adalah direktur harus cakap dalam memobilisasi orang untuk dapat memberikan kontribusi baik berupa ide, gagasan untuk dapat menemukan cara dan strategi yang baru. ${ }^{8}$

Sub tema kedua yaitu keterlibatan, dapat dilihat dari pengelolaan sumber daya manunsia yakni dengan memberdayakan dan melibatkan tenaga kerja yang masih muda dan memiliki antusiasme dalam bekerja yang sangat tinggi. Pernyataan tersebut dapat dilihat dari:

“... memang direktur merangkap jadi ketua panitia akreditasi, itu dengan seperti itu aja... mereka sudah pada sungkan... gitu ya... trik saya sih gitu ya... otomatis jalan ... la wong direkture lembur terus.. 'mosok nyong' ora ya ... otomatis jalan... otomatis begitu ... banyak yang bisa kita lakukan... ya memberi contoh kepada karyawan semua... seperti itu... komitmen, memberi contoh... terlibat..." (I3)

Pemimpin dalam hal ini direktur rumah sakit diharapkan memiliki kemampuan yang fleksibel dan adaptif. ${ }^{8}$ Dengan kemampuan tersebut maka direktur mampu untuk menjadi panutan bagi stafnya.

Sub tema ketiga yakni kepedulian. Direktur dituntut untuk memiliki kepedulian terhadap semua, disamping itu pemimpin juga berkewajiban untuk menjadi role model bagi setiap staf di rumah sakit. Hat tersebut dapat terlihat dari:

“ ... ya perlu 'ditlateni', dilakukan pendekatan terus menerus... dikasih contoh terus menerus... dimotivasi terus menerus, saya panggil, saya dekati dan jelaskan sendiri..." (I3)

“... untuk dokter yang sepuh-sepuh ya memang 'uangel' (sulit)... mungkin karena sudah sepuh ya, ya sulit juga... ya tapi tetap dikasih tahu pelanpelan...(sambil tertawa)... nah yang mantan-mantan itu yang malah "angel" (sulit)... karena senior... (tertawa) ya sudah... ditemui saja satu persatu, ya disampaikan, ya "tulung"(tolong) ya...ini,ini,ini ... kita mau akreditasi, dan saya juga menggunakan tokoh-tokoh dokter seperti misalnya saya menggunakan dokter $X$... nah, beliau kan tokoh... saya minta tolong beliau ... beliau yang 'ngoprak-oprak'( memotivasi)..."(I3)

Dikatakan oleh Hort, dkk dalam penelitiannya bahwa sumber daya manusia perlu dikembangkan melalui kebijakan yang berasal dari pemerintah. Termasuk pemberian insentif dan penghargaan yang memadai untuk mendukung program akreditasi. ${ }^{9}$ Dengan demikian diharapkan hal 
tersebut dapat meningkatkan motivasi bagi setiap karyawan untuk mau terlibat.

Sub tema empat yaitu pengawasan. Dalam menjalankan setiap program diperlukan fungsi pengawasan dari pimpinan, suport sistem yang memadai, sehingga semua staf dapat bergerak maju untuk mempersiapkan akreditasi. Tetuang dalam pernyataan:

“...tenaga-tenaga yang masih muda ini lebih mudah dibangkitkan semangatnya bu... tetapi kita harus arahkan dengan baik , menggerakkannya harus jelas mereka... kalau mengerjakan ini... ini... ini... caranya garus gini... gini... gini... trus mereka kerjakan..." (I2)

“ ...saya tidak dapat menjangkau semuanya... dibawah saya masih ada beberapa orang-orang yang membantu saya untuk ikut mengawasi ...." (I2)

Fungsi pengawasan dilaksanakan untuk memonitor kinerja dan apabila diperlukan dapat segera melakukan perubahan. Dengan fungsi pengawasan, direktur memastikan bahwa sumber daya yang organisasi digunakan dengan tepat sesuai dengan perencanaan yang ditetapkan. $^{9}$

\section{Tema 2: Komitmen pemilik dan manajemen}

Untuk dapat mencapai akreditasi seperti yang diharapkan, diperlukan dukungan penuh dari pihak pemilik rumah sakit. Diperlukan keterlibatan pemilik untuk dapat mewujudkan akreditasi. Suport penuh dari pihak pemilik dan pihak manajemen rumah sakit sangat diperlukan. Tema ini dibentuk dari dua sub tema, yaitu:
Sub tema pertama jalankan peran fungsi manajemen sesuai dengan porsinya. Setiap peran baik sebagai pelaksana manejerial dan pemilik dilaksanakan sesuai dengan ketantuan yang telah ditetapkan. Pernyataan ini terlihat dari:

"Fasilitas rumah sakit yang diperlukan juga harus disiapkan semua sesuai standar, dan disesuaikan dengan kemampuan dalam pengadaannya... tidak bisa memaksakan sesuatu...tapi setidaknya rumah sakit harus menyediakan peralatan dan fasilitas sesuai dengan standar..." (I2)

"Ya... owner terlibat semua... itu kan mereka ada kebijakan-kebijakan yang dari pemilik... tentang struktur organisasi, kemudian tentang HBL (Hospital by Laws), semua disahkan oleh pemilik... pada saat nanti dilakukan survei akreditasi, owner harus hadir. Mereka juga mengeluarkan kebijakan-kebijakan, owner sendiri juga memiliki pedoman... ya... sangat berperan memberikan suport... ya itu contoh suportnya kalau kita memerlukan dokumen-dokumen... mereka akan cepat memberikan..." (I3)

Strategi yang digunakan oleh pengelola rumah sakit terhadap SDM tersebut sesuai dengan fungsi manajemen menurut Terry yang meliputi fungsi perencanaan (planning), pengorganisasian (organizing), pelaksanaan (actuating) dan pengawasan (controlling). ${ }^{10}$ Pengelola rumah sakit melakukan perencanaan SDM dengan memilih setiap SDM yang dapat dilibatkan dalam proses akreditasi.

Sub tema kedua adalah bentuk dukungan dari pemilik/owner. Setiap owner dari rumah sakit memiliki peran penting dan 
berkewajiban memberikan dukungan yang sepenuhnya untuk dapat mencapai akreditasi rumah sakit. Pernyataan ini dapat dilihat dari:

“...pemilik rumah sakit dalam hal ini PT punya komitmen yang kuat... bahkan saya sendiri yang belum kepikiran akreditasi, pemilik malah mendorong kami untuk segera terakreditasi... jadi komitmennya kuat,... dan dukungannya juga kuat...” (I2)

“...yang harus juga terlibat dalam proses akreditasi adalah pemilik... pemilik itu harus peduli... juga pada kita... pemilik juga harus memberikan suport kepada kita.." (I1)

“...yang menjadi sangat prinsip ketika akan mempersiapkan akreditasi itu adalah bagaimana komitmen antara pemilik dan manajemen itu menjadi penggerak yang paling kuat... kalau kita karyawan itu kan tinggal mengikuti perintah dari pemilik dan manajemen... nah.. itu kalau komitmen antara pemilik dan manajemen itu yang menjadi dasar yang harus dibangun terlebih dahulu komitmennya..."(I5)

\section{Tema 3: Prosedur sesuai program}

Salah satu strategi yang dilakukan oleh sebuah rumah sakit menurut seorang Informan adalah akan mengikuti program khusus yang memang disiapkan untuk rumah sakit tipe $D$ tanpa dengan jumlah tempat tidur kurang dari 100 bed dan tanpa pelayanan subspesialistik. Yang disiapkan hanya 4 pokja. Program akan ditambahkan tiap tahun hingga total nantinya tetap 15 pokja. ${ }^{11}$ Pernyataan tersebut tampak dalam:

"Karena ada program khusus, jadi ada yang untuk rumah sakit type $D$ dengan jumlah tempat tidur kurang dari 100, belum pernah terakreditasi dan sub spesialistik itu bisa terakreditasi program khusus hanya 4 pokja saja, dari 15 pokja yang ada. Itu sih mungkin nanti yang kan terkejar... jadi targetnya akan 4 pokja khusus nanti setiap tahun akan kita tambah... jadi total tetap 15...." (I4)

Tema 4: Manajemen waktu

Strategi yang dilakukan untuk tercapainya akreditasi adalah dengan melakukan pekerjaan lembur. Diperlukan persiapan dari tenaga kerja untuk dapat melakukan pekerjaan secara lembur, dan bekerja lebih banyak. Hal ini seperti terungkap dalam pernyataan:

“ ... pokja-pokjanya, tim intilah yang menyusun akreditasi itu untuk menjadi bahan pokja, kemudian pokja - pokja baru mengaplikasikannya ... ya seperti itu... jadi intinya tim intinya yang lembur terus..." (I1)

“...tanaga kerja kita masih muda-muda dan masih kuat... mereka itupun, mereka masih siap untuk bekerja lembur dan bekerja lebih... bahkan diajak lari seperti itupun, mereka masih mampu" (I2)

“...karena setiap hari kita direpotkan... kenapa... setiap hari kita sudah sibuk dengan pekerjaan kita sendiri... ditambahi dengan pekerjaan akreditasi diluar jam kerja... ya itu kerja dobel...(tertawa)" (I3)

“...indikator penilaian itu justru ada di manajemennya... bagaimana tim manajemen mengatur stafnya untuk mengatur pekerjaan stafnya.. ya banyak yang lembur-lembur juga lho..."(I5)

Bekerja secara berkelompok, dengan pengaturan tertentu oleh direktur, dengan melibatkan banyak staf, dapat meningkatkan efek fasilitas sosial. Staf dalam hal ini tim 
akreditasi akan bekerja lebih keras apabila berada didalam tim dari pada ketika bekerja sendiri. $^{12}$

Mengatur karyawan dan menyiapkan karyawan untuk dapat bekerja diluar pekerjaan rutinnya menjadi sebuah tantangan tersendiri bagi manajemen. Hal tersebut juga sesuai dengan fungsi pengorganisasian dalam manajemen menurut Robin yakni manajer memiliki tanggungjawab untuk menentukan tugastugas yang akan dikerjakan, siapa yang mengerjakan, bagaimana tugas-tugas dikelompokkan, siapa yang melapor kepada siapa, dan dimana keputusan harus dibuat. ${ }^{12}$

\section{Tema 5: Strategi proses}

Dalam usaha yang dilakukan oleh rumah sakit dalam mencapai akreditasi banyak proses yang harus dijalankan. Strategi proses akreditasi ini dibentuk oleh tiga sub tema, yaitu:

Sub tema pertama adalah alur kerja. Proses strategi untuk mencapai akreditasi dimulai dari dibentuknya pokja-pokja (kelompok kerja), memberikan contoh, dan juga harus menguatkan dasar pondasi yang kuat dalam pemahaman terhadap akreditasi. Pernyataan tersebut terlihat dari:

“ ...kita pada tahap membentuk pokjapokja seperti itu... ya... kita akan membentuk pokja-pokja, karena kita benar-benar mulai dari nol... trus kita harus konsep memahamkan ...ini lo akreditasi.. seperti ini... seperti ini... beda dengan apa yang sudah kita lakukan..."(14) "...ya saya merangkap sebagai ketua akreditasi rumah sakit, ya otomatis harus terlibat... karyawan perlu dikasih contoh... memberi contoh terus menerus kepada karyawan semua..." (I3)

" ...nah... setelah fondasinya kuat baru kemudian kita action, seperti itu penginnya sih... apa namanya... survei simulasi, workshop, kemudaian survei yang sebenarnya... seperti itu sih maunya..." (14)

Pengaturan kerja secara berkelompok atau dengan membentuk tim-tim kerja, dibentuk dengan tujuan untuk meningkatkan motivasi bagi semua anggota tim. ${ }^{13}$ Dengan demikian anggota-anggota ini akan akan dapat memberikan hasil kinerja dan kontribusinya secara lebih efektif.

Menurut KARS perkembangan akreditasi rumah sakit di dunia sangat cepat. Perubahan dimulai dari perubahan standar yang semula berfokus kepada pemberi pelayanan, telah bergeser menjadi berfokus kepada pasien. ${ }^{11}$ Perubahan tersebut diikuti pula dengan perubahan metode survei yang semula hanya berfokus kepada struktur, telah berubah menjadi berfokus kepada struktur proses - keluaran. Hal ini dapat dikembangkan oleh setiap rumah sakit dengan membentuk strategi proses dengan cara membentuk pokja-pokja akreditasi, pelatihan, studi banding. Terlebih juga diperlukan pengelolaan sumber daya manusia dan sumber daya lain secara optimal oleh pimpinan rumah sakit. ${ }^{13}$ 
Sub tema kedua dalam strategi proses adalah adanya penyampaian informasi yang terus menerus dan berkesimambungan.

Pernyataan tersebut dapat dilihat dari:

“ ...semua akan kita lakukan... semua akan terprotap... semua akan terstandar... walaupun kita sudah ada, tetapi mungkin akan berubah semuanya, karena kita akan akreditasi... jadi ya secara tidak langsung mereka akan semakin tahu... penyampaiannya dengan per lisan, atau per rapat... nah seperti itu" (14)

“...semua berkoordinasi melalui pokjapokja itu... ya ada rapat-rapat juga... rapat manajemen... rapat panitia akreditas... ada sosialisasi..." (I3)

Dalam menyampaikan informasi diperlukan tenik penyampaian yang efektif. Komunikasi dapat dijalankan baik secara satu arah maupun dua arah sesuai dengan kebutuhan yang diperlukan. ${ }^{12}$ Dengan teknik komunikasi yang efektif, tentu akan meningkatkan hasil optimal terlebih dalam menyiapkan akreditasi.

Sub tema ketiga adalah adanya dukungan dari rumah sakit swasta yang lain. Rumah sakit swasta yang telah terakreditasi dapat berperan sebagai contoh untuk menyusun strategi dalam berproses mencapai akreditasi. Dukungan dari organisasi rumah sakit swasta juga memiliki peran penting untuk meningkatkan suport system bagi rumah sakit. Pernyataan tersebut dapat diperhatikan dari:

“...strategi yang kita lakukan juga adalah mencontoh dari rumah sakit-rumah sakit lain... em... yang sudah terakreditasi tentunya... seperti RS yang sudah terakreditasi, ya... kita mencontoh... ya walaupun kita tidak bisa menjiplak" (14)

“..kita juga dapat menghadiri bimbingan akreditasi di rumah sakit lain yang sedang dibimbing.. . kebetulan hal itu bisa kita lakukan karena kita ada kekerabatan yang baik dengan rumah sakit-rumah sakit lain... nah kita sering diundang, sehingga bisa belajar..." (14)

“... saat ini kita juga merasa sudah tidak sendiri lagi... dengan adanya ARSSI Barlingmascap (Asosiasi Rumah Sakit Swasta Indonesia Banjarnegara, Purbalingga, Banyumas, Cilacap) ini kita bisa saling belajar... ya memang ada rumah sakit yang sudah maju sekali... ada yang belum.. maka kita akan kerjakan dulu sebisanya... rumah sakit yang lain akan mendukung... kita mendapatkan keuntungan... karena kita dapat 'update' akreditasi ... "(14)

Akreditasi merupakan tantangan bagi rumah sakit-rumah sakit saat in. Dengan demikian tantangan tersebut mendorong rumah sakit untuk saling membantu, saling mendorong, saling memberi motivasi, hingga tujuan menjadi rumah sakit yang terakreditasi dapat tercapai. Kekompakan rumah sakit-rumah sakit tersebut mampu menciptakan motivasi sehingga dengan demikian dapat saling mempengaruhi antara yang satu dengan yang lainnya. ${ }^{13}$

Tema 6: Ciptakan lingkungan kerja kondusif.

Strategi lain yang digunakan oleh rumah sakit untuk mencapai akreditasi adalah dengan menciptakan suasana kerja yang senyaman mungkin. Dengan menciptakan suasana kerja informal untuk mendapatkan 
sesuatu yang formal. Pada dasarnya karyawan tidak menyadari hal tersebut tetapi karyawan dapat menikmati suasana yang menyenangkan, sehinga karyawan dapat bekerja mempersiapkan akreditasi secara lebih baik. Pernyataan tersebut dapat dilihat dari:

“... bagaimana kita membuat suasana menyenangkan... bagaimana kita bisa membuat suasana lembur akreditasi itu dapat menyenangkan, jadi saya buat seolah-olah kita sedang main... atau nongkrong, jadi disini suasananya kita bikin enak... kita siapkan musik, atau kopi, atau lain-lain, atau ruangan saya ini..."(I2)

" ...bagaimana kita buat seperti kita sedang main ke rumah sakit, kita nonton film rame-rame... jadi kita buat aktifitas kita adalah menyenangkan... karena kita memang masih muda-muda, jadi kita memang masih muda-muda... jadi saya ngga mungkin membuat suasana yang formal, karena kita akan kaku... jadi lebih baik kita bikin suasana yang cair..." (I2)

"Jadi prinsipnya saya dengan teman saya membuat suasana ini menjadi tidak formal, tapi justru mengadakan sesuatu yang formal tetapi dengan sesuatu yang informal, karena justru ini membangkitkan yang masih mudamuda..."(I2)

Strategi lain yang dapat dikembangkan oleh pemimpin rumah sakit adalah dengan menciptakan lingkungan kerja senyaman mungkin bagi stafnya. Bagaimana menciptakan suasana kerja informal untuk menghasilkan sesuatu yang yang formal. Suasana kerja yang kompleks dapat menimbulkan kebosanan dan ketegangan kerja bagi karyawan. Untuk menghindari hal tersebut perusahaan perlu menciptakan suasana santai dalam bekerja. ${ }^{14}$

\section{KESIMPULAN}

Strategi rumah sakit swasta di Purwokerto dalam menghadapi akreditasi adalah dengan membangun sumber daya manusia yang peduli terhadap rumah sakit. Membangun sumber daya manusia yang berkualitas, bekerja sesuai dengan ketentuan yang telah ditetapkan, dan membangun sistem yang baik dalam memberikan pelayanan kepada pasien, diharapkan mampu untuk membuat rumah sakit swasta terus berkembang dan mampu memberikan pelayanan bermutu kepada stakeholder secara memuaskan.

Selain pengelolaan sumber daya manusia, juga diperlukan strategi pengelolaan sumber daya lain baik fisik maupun fasilitas sesuai dengan kemampuan rumah sakit swasta. Lingkungan kerja yang nyaman juga mendukung diperolehnya efektifitas kerja staf yang memadai sehingga memudahkan keterlibat staf dalam mempersiapkan akreditasi.

Keterbatasan penelitian ini yaitu bahwa penelitian hanya dapat diselenggarakan pada empat rumah sakit umum swasta yang ada di Purwokerto, sedang tiga rumah sakit idak menyatakan kesediaanya untuk terlibat dalam penelitian.

Mempertimbangkan akreditasi bersifat wajib untuk semua penyelenggara layanan kesehatan di Indonesia, untuk itu peneliti 
menyarankan, penelitian selanjutnya untuk dilaksanakan bagi seluruh rumah sakit swasta maupun non swasta, baik rumah sakit umum, rumah sakit khusus, atau unit pelayanan kesehatan lain seperti puskesman ataupun klinik.

\section{TERIMA KASIH}

Terima kasih yang sebesar-besarnya penulis haturkan kepada segenap pihak yang terlibat dalam penelitian ini. Terlebih untuk segenap Direktur Rumah Sakit Swasta di Purwokerto, yang bersedia menjadi informan dalam penelitian ini. Terima kasih dan penghargaan yang setinggi-tinggi penulis sampaikan untuk segenap sejawat, yang telah memberikan suport dan arahan sehingga karya ini dapat dipublikasikan.

\section{KEPUSTAKAAN}

1. David, Fred R. Manajemen Strategi Edisi 10. Jakarta : Salemba Empat, 2010.

2. Huber, D. Leadership and Nursing Care Mangement. 5-Edition. Philadelphia: Sunners Elservier, 2013.

3. Menteri Kesehatan Republik Indonesia. Peraturan Menteri Kesehatan RI No. 12 tahun 2012 tentang Akreditasi Rumah Sakit [Online] 2012. [Dikutip: 2 April 2016.] www.djpp.depkumham.go.id.

4. Dinas Kesehatan Pemerintah Kabupaten Banyumas. Data Rumah Sakit di Kabupaten Banyumas [Online] 2016. [Dikutip: 10 Agustus 2016.] http://www.banyumaskab.go.id.

5. KARS. Daftar Rumah Sakit Terakreditasi Versi 2012 [Online] 2016. [Dikutip: 2 Mei 2016.]

http://www.accreditation.kars.or.id/acredita tion, report/report_ac.credited.php.

6. Hajiroh, Marni. Hasil Penelitian Universitas Negeri Yogyakarta. [Online] 2012. [Dikutip: 20 http://www.google.ac.id/seacrh?q=studi\&o $\mathrm{q}=$ studi+fenomenologi.

7. Smith, Jonathan A, Flowers, Paul dan Larkin, Michael. Interpretative phenomenological and research. Los Angeles : Sage, 2009.

8. Bateman, Thomas $S$ dan Snell, Scott $A$. Manajemen Edisi 10 Buku I. Jakarta: Salemba Empat, 2014.

9. Hort, Krishna, Djasri, Hanevi dan Adi, \& Untarini. Regulating the quality of health care: Lessons from hospital accreditation in Australia and Indonesia. . Working Paper Series, Mei 2013, Vol. Number 2B, AusAID Knowledge Hubs for Health. The University of Melbourne.

10.Terry, George. Dasar-Dasar Manajemen. Jakarta : P.T Bumi Aksara, 2010.

11. KARS. Pedoman Tata Laksana Survey Akreditasi Rumah Sakit. Edisi 3 [Online] 2013. [Dikutip: 6 Mei 2014.] http://www.scribd.com/doc/269550204.

12. Batteman, Thomas $S$ dan Snell, Scott. Manajemen Edisi 10 Buku 2. Jakarta: Salemba Empat, 2014.

13.Robins, Stephen $P$ dan Judge, Timothy A. Perilaku Organisasi. Edisi 16. Jakarta: Salemba Empat, 2015.

14. Munijaya, A.A Gde. Manajemen Mutu Pelayanan Kesehatan. Jakarta: Kedokteran EGC, 2014. 